\title{
Dutch, the Iron Lady and Latin America. The Anglo-American Special Relationship in Latin America under Reagan and Thatcher
}

\author{
Sally-Ann Treharne
}

School of History, UCC

Margaret Thatcher and Ronald Reagan made a formidable team in the international political environment of the 1980s. Their close working and indeed personal relationship shaped the future of Western European defence, facilitated the eventual fall of Communism, and brought international recognition to the Anglo-American Special Relationship. It was a testimony to a joint commitment to a renewal in transatlantic relations following a lull in the 1970s. Both leaders had vastly different personalities with Mrs. Thatcher often portrayed as Reagan's proverbial 'poodle' in such satirical shows as the infamous Spitting Image. However, in reality the relationship was in many ways led by the British Prime Minister who was willing to assert her considerable influence over her American counterpart at any given opportunity. The relationship ore, was indeed 'Special'. It went beyond the normal political protocol associated with bilateral cooperation and consultation. It was a relationship that endured many highs and lows during their simultaneous leaderships. It was an association based upon a mutual respect and admiration and a close familiarity that frequently impelled both leaders to forego their own national interests in order to safeguard the coveted Special Relationship. This was often, to the dismay of close advisers and administration officials. It is this unique and intangible bond which was invariably tested by numerous obstacles that makes analysis of the Anglo-American Special Relationship such a fascinating and challenging topic of research.

My dissertation focuses upon the Special Relationship under these influential world leaders. It assesses the impact of both Thatcher and Reagan's differing domestic and foreign policy objectives in the Latin American and South Atlantic region upon a renewal in close transatlantic relations on their accession to power. This region was of considerable importance to a Reagan administration that sought to roll back the perceived Communist threat in its own 'back-yard'. In order to deter the Soviet Union and Cuba from gaining a foothold in fragile countries in this politically volatile region the United States was prepared to undertake unilateral action which was often of dubious legality and covert in its nature. In contrast, the United Kingdom sought to distance itself from the region by promoting decolonization and self-government. At times, these differing foreign policy objectives clashed when both the United Kingdom's and American strategic hemispheric interests were threatened by the actions of the other. Although both leaders were united in their anti-Communist rhetoric, the region ultimately brought to the fore significant ob- 
stacles which threatened to invalidate the relationship. Most notable were the cases of: the Falklands War in 1982, the US invasion of Grenada, a member of the British Commonwealth, in October 1983, the contentious Anglo-Guatemalan dispute over the territorial integrity of Belize and the infamous US involvement in Nicaragua. These cases and others challenged the strength of the Special Relationship and highlighted a political asymmetry which was detrimental to the future of Anglo-American relations.

\section{Case Studies in Anglo-American interests in the South Atlantic and Latin America: The Falklands War and Grenada}

The Argentine invasion of South Georgia and the Falkland islands, after decades of protracted negotiations with the British, resulted in a conflict of interest for the Reagan administration. The United States was placed in the unenviable position of having to choose between two allies. On one hand Argentina provided the US with a non-Communist ally in the Latin American region. On the other the United Kingdom was a close ideological ally with whom the US had a well -documented, shared history. Mrs. Thatcher expected her American ally to support the British in the war and was disappointed when the US decided initially to remain neutral. My research assesses the crisis and Mrs. Thatcher's attempts to convert the Reagan administration to the British point of view. It addresses the US Secretary of State, Alexander Haig's mediation efforts, in what was termed 'shuttle-diplomacy' to resolve the issue and provides an in-depth analysis of Anglo-American consultation during this time.

The US invasion of Grenada was yet another obstacle in the path of continued and improved Anglo-American relations in the early 1980s. The decision by President Reagan to intervene in the internal affairs of one of the Queen's dominions and to deliberately decide not to tell Margaret Thatcher of his plans resulted in a significant blow to the Special Relationship. The dissertation addresses the consequences of this decision upon the renewal in transatlantic relations. It also analyses the circumstances leading up to the invasion, particularly with regards to the legality of the invasion and Anglo-American consultation.

\section{Belize and Nicaragua}

Yet another area of concern to the Special Relationship was the Anglo-Guatemalan dispute over the territorial integrity of Belize during the leaderships of Ronald Reagan and Margaret Thatcher. Guatemala had claimed the territory of Belize for centuries and the British were not prepared to cede on the issue despite the fact that Belize was looking for full independence from the United Kingdom. In the 1980s Britain agreed to grant independence to Belize within the confines of the British Commonwealth. Guatemala however, was not 
prepared to recognise this and made sporadic threats to invade Belize. The Reagan administration decided to become actively involved in mediating the dispute but it would appear that it had its own strategic hemispheric interests in mind. The dissertation critically assesses these interests in order to determine their impact upon the Special Relationship and to determine their strategic importance to the government of Ronald Reagan.

Nicaragua was an area of considerable interest to the Reagan administration. It resulted in a very public condemnation of the US methods of assisting counterrevolutionaries which came to light in the infamous Iran-Contra scandal of November 1986 onwards. The research focuses upon Mrs. Thatcher's views of American unilateral action in the country. In looking at these and other issues that crossed over in to the Anglo-American sphere, such as, - the Laker Airways dispute and the Westland affair, the dissertation hopes to address the misconception that Mrs. Thatcher was in some way politically subservient to her American counterpart. It is necessary therefore, to provide a detailed analysis of AngloAmerican Relations during the 1980s in order to highlight the importance of the above mentioned obstacles in the Latin American and South Atlantic region. In doing so, it will determine the validity of such a widely used term as the Special Relationship. It will also determine the joint commitment that both Reagan and Thatcher had to this relationship by striving to improve relations despite these many obstacles.

\section{Accessing material in the United Kingdom and the United States}

As the focus of the research is contemporary history this brings with it some significant difficulties. It has proved somewhat problematic to gain access to all the relevant materials needed to provide a comprehensive analysis of the Anglo-American Special Relationship. It has been a challenge to gather the necessary information in particular in the United Kingdom. UK government rules dictate a thirty year gap between the historical events and the releasing of documentation pertaining to those events such as Prime Ministerial papers. A Freedom of Information Act (FOIA) request can be made for material, but this is a slow and often frustrating procedure. Therefore, it is often necessary to rely upon public records such as Parliamentary Bills, Commands, debates in the House of Commons and reports for example, as sources of information. These can be difficult and often timeconsuming to navigate, but they are unfortunately, a necessary evil in the research process.

Margaret Thatcher's papers are located at the Churchill Archives Centre in Cambridge and have provided a limited amount of information due to the Thirty Year Rule. Consequently, one must look at other actors in her Cabinet at the time in order to gain an insight into the Thatcher government, its domestic and foreign policy objectives and, of course, its relationship with the Reagan administration. These include Nicholas Ridley, former Financial Secretary of the Treasury and Secretary of State for Transport, the Environment, 
and Trade and Industry, John Nott, the Secretary of State for Defence and the leader of the opposition, Neil Kinnock. All of their personal papers provide interesting and revealing information on the Thatcher government and its policies during this period of time. These papers along with interviews of Mrs. Thatcher's close advisers and confidants such as Charles Powell, Mrs. Thatcher's Foreign Affairs Private Secretary during her leadership and Bernard Ingham, the Prime Minister's Chief Press Secretary, build a picture of her Premiership and of the woman herself. These interviews therefore, have been invaluable to the development of my research.

\section{The importance of US archival research}

Greater access to primary documents is available in the United States principally, in the Ronald Reagan Presidential Library in Simi Valley, California. It is here that most of the information with the exception of some documents still deemed to be too sensitive in nature, are held with regards to the Reagan administration. There is a wealth of documents located in innumerable files that have to be slowly sifted through under the watchful eye of an ever-present archivist. These files although labeled, have yet to be indexed which ensures days if not weeks of back-breaking research. However, the pay-off is undoubtedly the little pieces of information found in White House cables, situation room messages or reports, that help tie your research together. The archives also provide significant material on the Thatcher government which is unavailable for access in the United Kingdom such as Prime Ministerial cables, messages and intergovernmental correspondence. Consequently, the Ronald Reagan Presidential Library archives have been an invaluable source during the research process. Gathering such information is both time consuming and expensive yet, it is ultimately very rewarding as it enables your research and argument to strengthen and develop in a clear and consistent manner. Thankfully, some financial assistance is available from the School of History in the form of competitions for travel bursaries. These bursaries proved invaluable as the Presidential Library in Simi Valley does not provide grants to overseas research students. Doctoral students in the arts, social sciences and humanities are not generally well resourced and have to depend substantially on personal funding. Therefore, the departmental travel bursaries were of significant help to me during the research process.

The Special Relationship under Margaret Thatcher and Ronald Reagan has been well documented by many noted academics and historians. Nonetheless, the Latin American and South Atlantic region has been completely overlooked as a vantage-point from which to assess this unusual bilateral relationship. This neglect ensures that preconceived notions about Anglo-American relations in the region that prevailed during the period in question can be tested against the evidence. The Special Relationship helped shape the policies of both leaders during a time of great political uncertainty. It was at times, besieged by obstacles emanating from the turbulent Latin American region. Individual strategic interests 
in the hemisphere threatened at times to overshadow and possibly destroy both leader's tentative efforts to renew and strengthen Anglo-American relations. Yet the close working and personal relationship between President Reagan and Prime Minister Thatcher survived and indeed, flourished during this important period of Cold War history. Moreover, it is this commitment and desire to improve bilateral relations, to strengthen communication and cooperation in the face of often competing foreign policy objectives that makes the Anglo-American Special Relationship such a compelling area of research.

Sally-Ann Treharne is a final year PhD student in the School of History under the supervision of Dr. Mervyn O'Driscoll 